\title{
FIELD NOTES FOR AMATEURS
}

\author{
Sevasti-Melissa Nolas and Christos Varvantakis
}

\begin{abstract}
In this article we develop the idea of ethnography as a practice of desire lines. Lines of desire are pedestrian footpaths that are at once amateurish and playful, and that deviate from the grids and schemes of urban planners. We argue that ethnography has always been so at the same time as also being highly professionalized. The article explores these tensions between desire lines and professionalization as they became evident to us during a funded, international multi-modal ethnographic study with children-a study, we argue, that rendered us childlike. We conclude that being childlike and 'out of line' is an appropriate and necessary response for knowledge creation at a time of heightened professionalization in the academy.
\end{abstract}

Keywords: desire lines, ethnography, neo-liberal university, playing, researchers' agency

This article reflects on the ways in which anthropologists, and ethnographers more generally, might maintain the kind of creativity essential to exploring lived experience in a contemporary work environment that prioritizes a pernicious sort of bureaucracy, often described as 'neo-liberal', that often makes the quintessentially creative practice of ethnography more difficult. Neo-liberalism has no doubt changed the processes of knowledge production and the working conditions for many of us, not least those precariously employed on shortterm, part-time, and other (e.g., zero hours) tenuous employment contracts. The 'neo-liberal university' has been variously described using metaphors of war ('under siege') and protracted conflict ('occupation'), and depicted as market-driven, rife with intensified competition, individualistic and career focused, and endlessly audited and monitored, that is, a place in which practices of sharing and openness are exceedingly difficult (cf. Dalsgaard 2013; Giabiconi 2013; Graeber 2014; Le Courant 2013; Rivoal and Salazar 2013). ${ }^{1}$ 
The term 'neo-liberal' is, however, controversial (cf. Eriksen et al. 2015). As early and then mid-career researchers who have worked largely in Northern European higher education institutions for the last 10-15 years, we recognize the above description of the workplace all too well. It has its dehumanizing and alienating moments. But it also has its moments of sociality. The same period of time for us was also replete with lived experiences, and now memories of collegiality, kindness, solidarity, and many a 'shared drink' (a trope to which we will return to presently). As Jana Bacevic (2018) argues, the metaphors of war-and the grand narratives of neo-liberalism, we might say-used to describe the contemporary university obscure the more complex economic and political contexts we work in and the agency that we as academics have therein (and by extension, when we go into the field, the agency of our interlocutors and their practices of making lives livable). Such agency, Bacevic goes on to say, can be more than just reactive or resistant; it can also be creative and transformative. However, paths to creativity and transformation are not straightforward. They are instead replete with contradictions, which hover somewhere between reaction and creativity.

With an established research interest in agency, lived experience, collective action, and solidarity more generally (Nolas 2014; Nolas et al. 2016, 2017; Varvantakis 2018), ${ }^{2}$ in this article we turn the lens on ourselves and, drawing on a reflexive narrative of ethnographic research with children, delve into some of the complex and contradictory terrain of creative and transformative knowledge production in the 'neo-liberal university'. Our reflections are grounded in the European Research Council (ERC)-funded Connectors Study (2014-2019), a multi-modal ethnography exploring the relationship between childhood and public life with five- to eight-year-olds and their families over a three-year period in three cities (Athens, London, Hyderabad). The study was led by Nolas, while Varvantakis was the research fellow and study lead in Athens. Most of the fieldwork took place in children's homes and/or in their areas. A multi-modal ethnographic strategy was used, including children's photography, walking, talking, participant observation, and mapping. We begin by describing our experiences and the labor of doing ethnographic research with children from a diverse demographic who live in urban centers. ${ }^{3}$ We present these experiences here for their value in thinking about researchers' agency in the neo-liberal institution.

\section{Horsing Around: Becoming Childlike}

During our fieldwork (October 2014-June 2016), we spent a lot of time playing with the study children as part of our participant observation. Playing is not an unusual activity when doing ethnographic research with children (Katz 2004; 
Montgomery 2009), but less common are narratives about researchers playing with children-what this looks and feels like in practice, and what, if anything, it does to researchers.

Playing was not part of any original research methodology, and our study was not a study of children's play. Engaging in play often made us feel derailed, 'out of line' with our research strategies and fieldwork plans. We experienced this encounter with children's play in terms of methodological ineptitude, as well as ineptitude at playing. Many of the methods (walking, photography, mapping, etc.) that we brought into children's lives were rejected by some children or were subverted in both overt and tactical ways by others. We often lost the many games we played with the children and got made fun of for taking too many pictures, for our handwriting (see Aruldoss 2018), for repeating ourselves, and for our lack of knowledge about the current state-of-the-art cartoons, movies, music, and lots more. We often left children's homes feeling awkward, de-skilled, frustrated, and idiotic. Our research methods were not 'working', and we felt like terrible researchers, given that we had done little else but play.

All the play we were recruited into involved our adult professional bodies. Our adult bodies, with professional researcher identities through institutional affiliations, wandered amid epic battles of Lego Star Wars, dragon quests, medieval wars with moats and castles, Hot Wheels car races, trampoline jumping championships, and much, much more, not all of which we entirely comprehended. Not only that, we were also gendered bodies. Parental bodies (we are both parents to similarly aged children). Tired bodies. Bodies in pain. Hungry bodies. Bodies occupying that ethnographic present while also oriented toward a past (i.e., not having slept properly at night because of a toddler) and a future (i.e., with the same toddler waiting back home to play with us).

When, we often wondered, would it be appropriate to gently interject, for a third or fourth time, to remind our interlocutors of that question we had asked them in their bedroom/living room/garden/balcony earlier, the answer to which we were still curious about and, actually, kind of needed? Or should we surrender to these other worlds and acknowledge the enjoyment, also very much a part of these experiences as we laughed with children and at ourselves, of being spirited away, our own bodies caught up in own desires, playful beyond the professional, lost in the battles that were raging in front of us? Doing otherwise would indeed leave us 'game over' should we absentmindedly occupy ourselves with research questions instead of better defense strategies.

So what happens when we allow ourselves to be 'thrown off course', to be taken 'out of line'? And how might this help us think about creative practice in the so-called neo-liberal academy? An important thing that we found out during those years in the field is that, just like the messiness of everyday life, so too the fluidity of identities does not switch off at the boundaries of fieldwork 
hours. The liminal tropes of play are, in fact, very good reminders of this. As we came to realize, identities in play, particularly in deep and engaged play, are not set in stone but rather are fluid and interchangeable. One can be Darth Vader one moment and Obi-Wan Kenobi the next, and then be both Darth Vader and Obi-Wan Kenobi simultaneously, just before transforming once again into a dozen Stormtroopers.

Or, as was the case on the two separate occasions documented in the photographs below, it might take just a moment for one to turn from a researcher into a detective and then a pirate, or from a researcher into a seal (see figs. 1 and 2). Or, likewise, for a lollipop to turn from a detective's magnifying glass into a pirate's eyepatch, or a piece of cloth into a seal's fur coat. This multiplicity, plurality, and interchangeability of identities in play has led us to rethink our own professional and personal positionalities and, alongside those, the ways in which ethnographic knowledge, which we recognize as inherently creative, is produced in the present historical moment. If you cannot beat them, join them. And so, rather than resisting children's play, we have not only engaged in it, but have also reflectively transferred what we have learned into our research practices and ontologies.

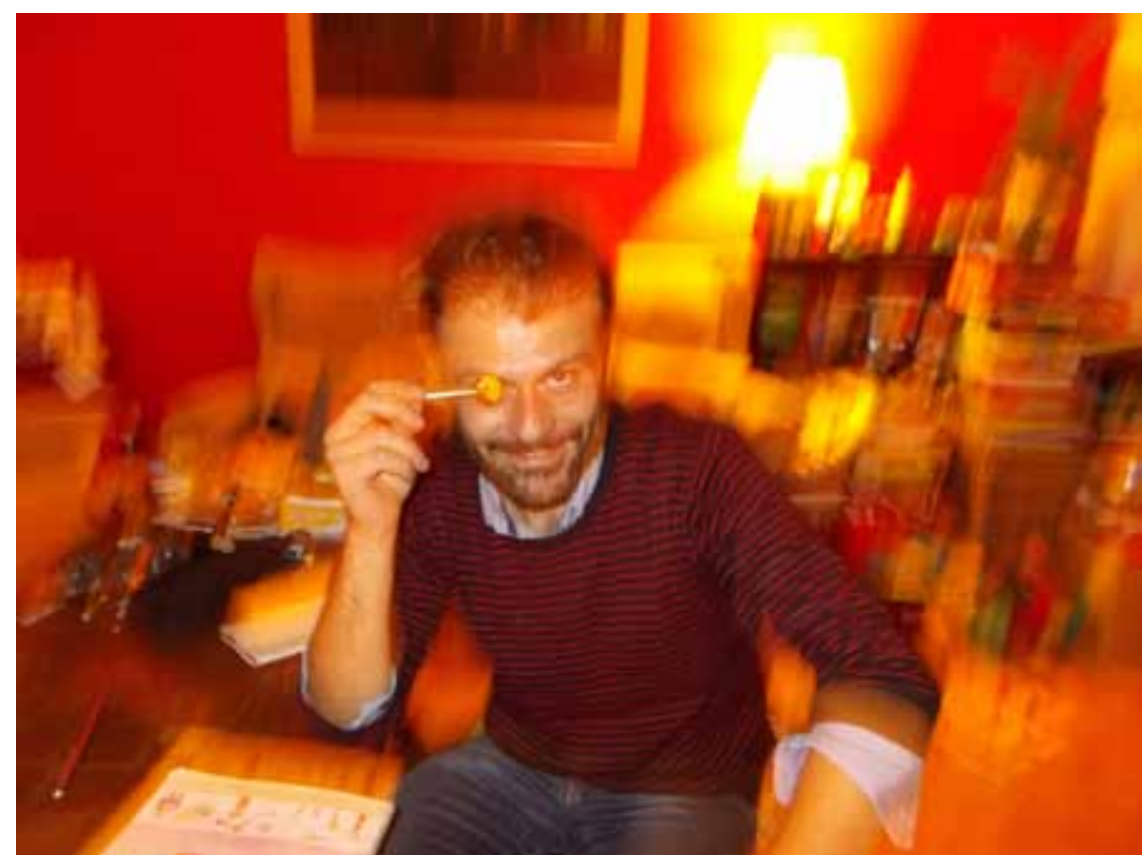

FigurE 1: Is this an ethnographer? A pirate-detective in Athens. Photograph by Vasiliki, age 7. 


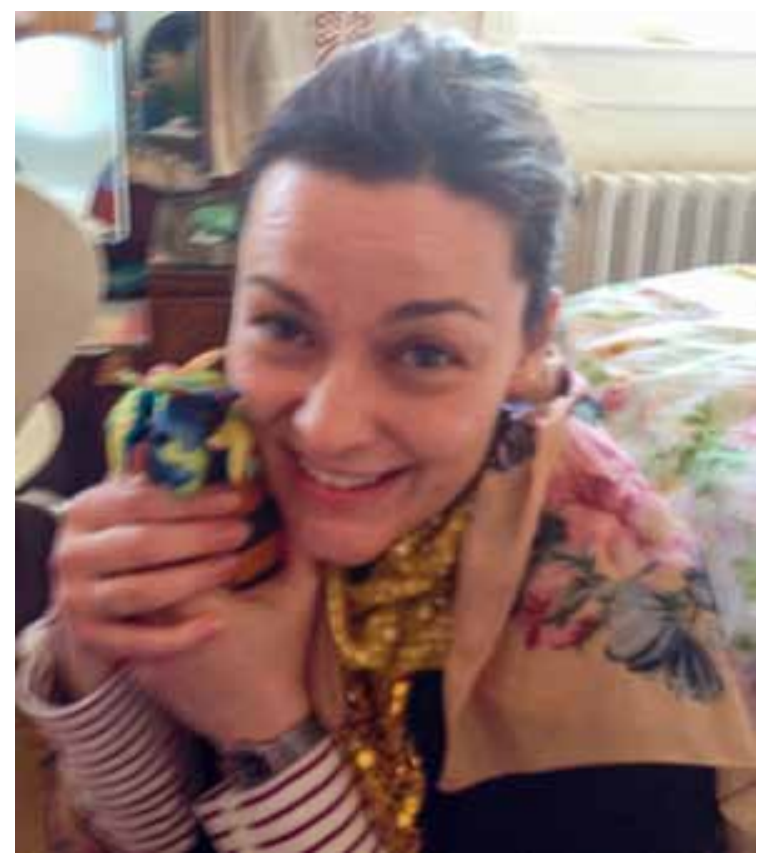

Figure 2: Is this an ethnographer? A seal in London. Photograph by Erica, age 7.

\section{Many a 'Shared Drink' among Amateurs}

It is not unusual for long-term ethnographic work to mimic the lives of informants (Sedgwick 2018; see also Nieuwenhuys 2010). Regarding play in particular, Katz (2004: 96-108), drawing on the work of Walter Benjamin, argues for the mimetic faculties of play. Accordingly, play is viewed as mimetic, affording opportunities for repetition and difference in encounters with the Other and the reproduction of the social. As Katz puts it: "Play is both a form of coming to consciousness and a way to 'become other"” (ibid.: 98). Mimesis is "to get hold of something by means of its likeness"; it is both a copying and "a palpable, sensuous, connection between the very body of the perceiver and the perceived" (Taussig 1993: 206). Katz (2004: 98) argues that it is those flashes of insight that emerge through play (conceived of as mimesis) that constitute "a moment of invention."

Yet there is something about play, and becoming childlike, that jars considerably with the professional straight lines that we are expected to follow in the contemporary workplace-the research strategies, career tracks, and impact agendas, to name a few. It took us over a year to engage meaningfully 
with children's play as something of significance, and something that was also affecting us. We both vividly remember the moment of disclosure at a team meeting in our Brighton office, at the time, during which each of us, together with our colleague Vinnarasan Aruldoss, tentatively ventured to share our doubts about having spent the first phase of fieldwork 'just playing'. If the 'neoliberal academy' has become a place in which practices of sharing and openness are exceedingly difficult, how and where do we continue to communicate with each other? How might we deal with the embarrassment and intrigue of having been transformed from professional researchers into sea dwellers of various kinds, as the case may be? Do you 'tell'? And if so, whom do you tell? Michael Taussig offers a couple of useful tropes to help answer these questions.

In November 2009, Taussig gave a talk at the Tate Modern in London as part of the series "Anthropologies of the Present." 4 During the Q\&A, a male voice asks if Taussig might offer "some advice for people trying to write their own field notes." In his response, Taussig reflects on the ways in which knowledge is produced in anthropology compared to other disciplines (e.g., psychology), concluding that being an anthropologist is best understood through the lens of "the nineteenth-century world of the amateur." The word 'amateur', with which Taussig chooses to describe ethnographic practice, derives from the French 'to love'. An amateur is someone who engages with a pursuit on an unpaid basis as a non-professional, for the love of it. The term 'amateur' also has negative connotations, such as ineptitude, and Taussig alludes to the anxieties such connotations cause the anthropologist, who becomes "prudent, cautious, frightened" to talk about his or her work, perhaps doing so only in the intimate space of a shared drink. He jokingly tells the audience member that his question is "out of line," suggesting that anyone who wanted to formalize the ethnographic process is "weird," while at the same time proposing that there is no secret in doing ethnography. "So where do you go from there?" Taussig asks the audience. "Do you maintain secrecy and ignorance, or do you expose it and maybe ruin it?"

It is not our intention to provide a normative response to the audience member's question posed to Taussig, which, incidentally, we see as going beyond the recording of field notes and extending to ethnography as a creative practice more broadly. We agree with Taussig that any formalization would be unproductive. Yet we are not so sure that being 'out of line' (at the same time acknowledging the humorous tone of Taussig's gentle admonishment) should not be promoted more as an ethical rebuttal to following straight lines. Indeed, we would argue that it is the very thing that is required to maintain the kind of creativity that is essential to exploring lived experience and everyday life, and doing so in a livable way. For us, being 'out of line' came in the guise of playing with children and becoming childlike. This is what threw us 'off course' from the well-defined professional narratives we were used to producing (albeit 
it uncomfortably for both of us). In the process, playing also inadvertently afforded the creation of socialities and solidarities (see fig. 3) that can sometimes go amiss in the contemporary workplaces of higher education.

\section{Following Desire Lines}

What might we make of the decision to surrender to and experience children's play in the first place, and how does this relate to maintaining the creativity of ethnographic practice and surviving and/or thriving in the violence of the neoliberal institution? It is a decision that sits uncomfortably with the logic of the

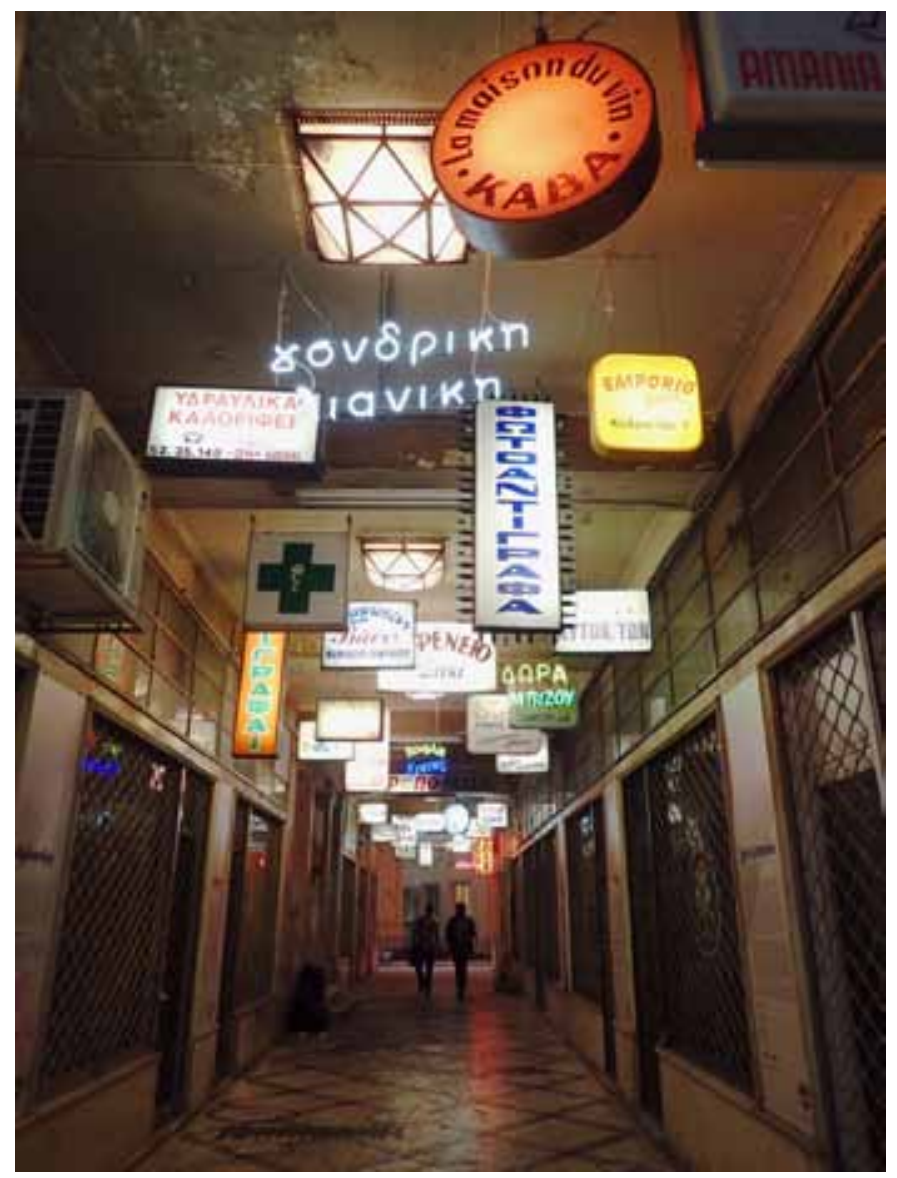

FigURE 3: Researchers Christos Varvantakis and Vinnarasan Aruldoss in an Athens arcade en route for a drink after a team meeting, February 2016. Photograph ${ }^{\odot}$ Melissa Nolas 
professionalized research practice and at first looks like a paradoxical way to respond to pernicious bureaucracy. Yet to wander off, following what we refer to as lines of desire (see fig. 4), is precisely the epistemology of ethnography (Bourdieu 1999), and to communicate such walkabouts falls within the spirit of anthropology as a generous, open-ended, comparative, and critical enterprise (Ingold 2017).

'Desire lines' is a term that emerges from urban planning to describe the paths that pedestrians make across an urban or rural landscape that deviate from those paths intended by planners (e.g., sidewalks, pavements, roads). Desire lines invoke a definition of desire as the cultivation of compulsive, perpetual, and unbounded curiosity. Here desire is understood as a productive force (Deleuze and Guattari 1983) that drives our investment in the world (Bourdieu 1999; Lutz 2017). Lines and line making are an integral part of human activity (Ingold 2007). Straight lines, and straightness, are often associated with development and progress (Varvantakis 2016). Geographically, this is

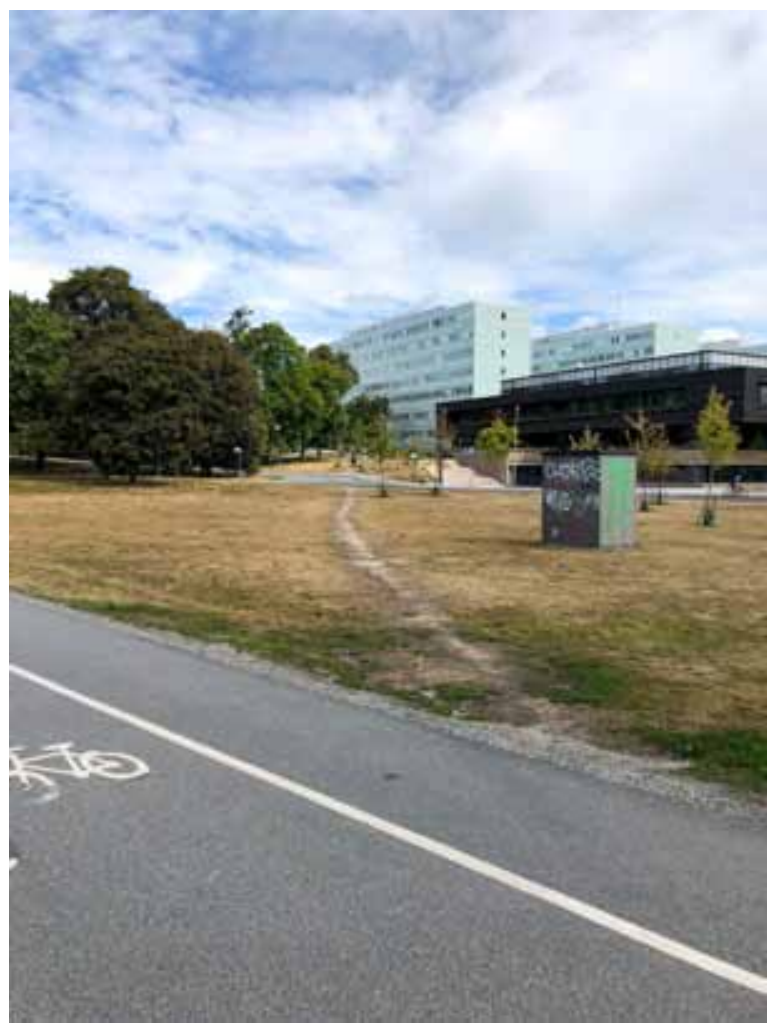

Figure 4: A desire line at Stockholm University, taken during the EASA conference in August 2018. Photograph ${ }^{\circledR}$ Melissa Nolas 
illustrated, for example, in city planning, with New York City as the archetypal example of "a city built upon the idea that the most efficient way of organizing social life and human bodies is through straight lines" (Irving 2017: 40). Straight lines are also pervasive in educational settings from primary school to higher education, as if lining up students represents an entire society falling in line: "If bodies can be put in order, thoughts can be put in order and eventually a whole society can" (Varvantakis 2016: 263). When walking without a map or itinerary and wandering city streets or rural fields, desire lines offer the opportunity for chance encounters, for discovery, and for wonder (Benjamin [1973] 1997; Jacobs 1961; Stavrides 1999: 118).

In a higher education context, where most of us encountered ethnography for the first time, straight lines are increasingly the norm. The desires that drive amateurs have been forced to become aligned with regulatory mechanisms as opposed to following their own energies (Morley et al. 2014: 457). This is demonstrated through doctoral training as well as funding applications. In the former, students are now expected to be able to demonstrate the acquisition of knowledge, skill, and experience, often broken down into distinct domains of learning that can and should be mapped. The professionalization of doctoral training in the UK is an example, along with the emergence of educational services such as Vitae ${ }^{5}$ or the development of 'training needs assessment' at the doctoral level. Contemporary research councils are also increasingly seeking project proposals that can demonstrate a discernible 'pathway to impact' at the stage of proposal. Furthermore, there is a trend and preference for larger funded projects, of which ours is an example.

In order to navigate this grid-like system, ethnography (and other qualitative research practices) are becoming 'methods', despite vociferous opposition to such an outcome (Ingold 2017). ${ }^{6}$ Methods are highly codified and professionalized approaches to finding out about the world and reporting this learning to peers (primarily), and many excellent publications about 'how to do' ethnography exist to help new researchers navigate their way around the grid (e.g., Brown et al. 2017). Ethnography, however, conceived of as a method, prompts a narrative of research practice that smooths over and straightens out the twists and turns of being in the field and of messiness, which our and others' experiences suggest are the very essence of creativity. It is then left to individuals, alone, to discover such messiness-its excesses and awkward emotionality, and its ontological meanings-and to then face the dilemma of whether to surrender to and disclose such experiences. To remain silent is to limit the opportunities for education and transformation, for ourselves as well as our colleagues and students. While respecting that disclosure might not be for everyone-and indeed for those at the beginning of the process of crafting professional narratives and practices, doing so may make them additionally precarious-we take the position that for those of us who can, it is an ethical 
imperative to resist the teleological nature of post-industrialized narratives that are "frantic for resolution" and to communicate "that sometimes the shit stays messy" (Nelson 2016: 53).

\section{Researcher Agency in Complex Economic and Political Times}

Deleuze (1994: 139) describes thought as a fundamental shock to the system that "may be grasped in a range of affective tones: wonder, love, hatred, suffering" but can only be sensed. Our encounters with childhood in Athens and London forced us to rethink our ethnographic practice. Our initial puzzlement, embarrassment, and sometimes even despair, as well as wonder, at being dragged into play have given us a way to rethink research practice in which, among other things, we attempt to theorize aspects of play in relation to their radical world-makings and un-makings and, in return, their significance for rethinking prefigurative political theories (Nolas et al. 2016) and other political categories (publics, commoning). At the same time, desire lines provided a metaphor for situating play, one form of action, in a particular time and space-the university workplace between 2014 and 2019. Desire lines exist in relationship to urban thoroughfares, often cutting across straight lines and/or unfolding beside them. The concept of desire lines helped us to co-exist with the grid-like practices of pernicious bureaucracy. Over time, we began to engage with the idea that in order to maintain the kind of creativity essential to exploring lived experience, we might conceive of ethnography as a practice of forging desire lines.

We would argue that such a practice requires certain conditions: openness and the time to be present in these encounters and with our interlocutors, as well as the conviviality that developed between us to talk about them. The realization that sustained play with children was 'thought', in the Deleuzian sense, did not register right away. It took a good nine-month period to render the encounter re-cognizable in the first instance as previously described, a re-cognition that did not involve theory or methodology but time to sit, uncomfortably, with the echo of such encounters and to hold the social world at "an awkward angle ... in order to see it differently" (Gidley 2009: 529). It was a time during which a process of 'unlearning' (Kapferer 2018: 29; see also Sassen and Warburton 2014) in order to understand took place as we slowly disabused ourselves, and others, of the notion that play was purely developmental, educational, or recreational (the most widely recognized conceptualizations of play) and entertained the idea that it could be political too (cf. Guggenheim et al. 2017; Rosen 2017). What was initially experienced as awkward and embarrassing-upending our professional identities and well-thought-out methodology and rendering us periodically idiotic (Guggenheim et al. 2017)—was, through the risk that disclosure always entails, rendered a force for creativity and transformation. 
Over time, we found ourselves mimicking various playful practices in our own research methods. Analysis is a case in point. The issue of analysis for ethnography has recently come to the fore. Martin Holbraad et al. (2018) describe the ambiguous nature of analytic practice in ethnography as a practice that occurs between theory, method, and ethnography, between field and the desk, between ethnographies past and present. The comment 'between field and the desk' is particularly pertinent here. As a research team whose members were geographically distributed, we met up face-to-face twice a year and were in continuous e-mail communication in between, as well as having regular Skype calls. ${ }^{7}$ We also shared, read, and discussed each other's field notes. In between periods of fieldwork, we continued to talk about our research, our encounters with children and their families, what we learned and how this made us feel, and how this related to the existing literature, ethnographies of childhood past and present. Some of these discussions took place in office spaces, while many were more ephemeral, but no less meaningful, and took place during walks to and from conference venues, from the office to a place to eat, as well as over dinner, with Taussig's 'shared drink' constituting a key moment of analysis (see fig 5). As such, much of our sensemaking, for that is part of what analysis

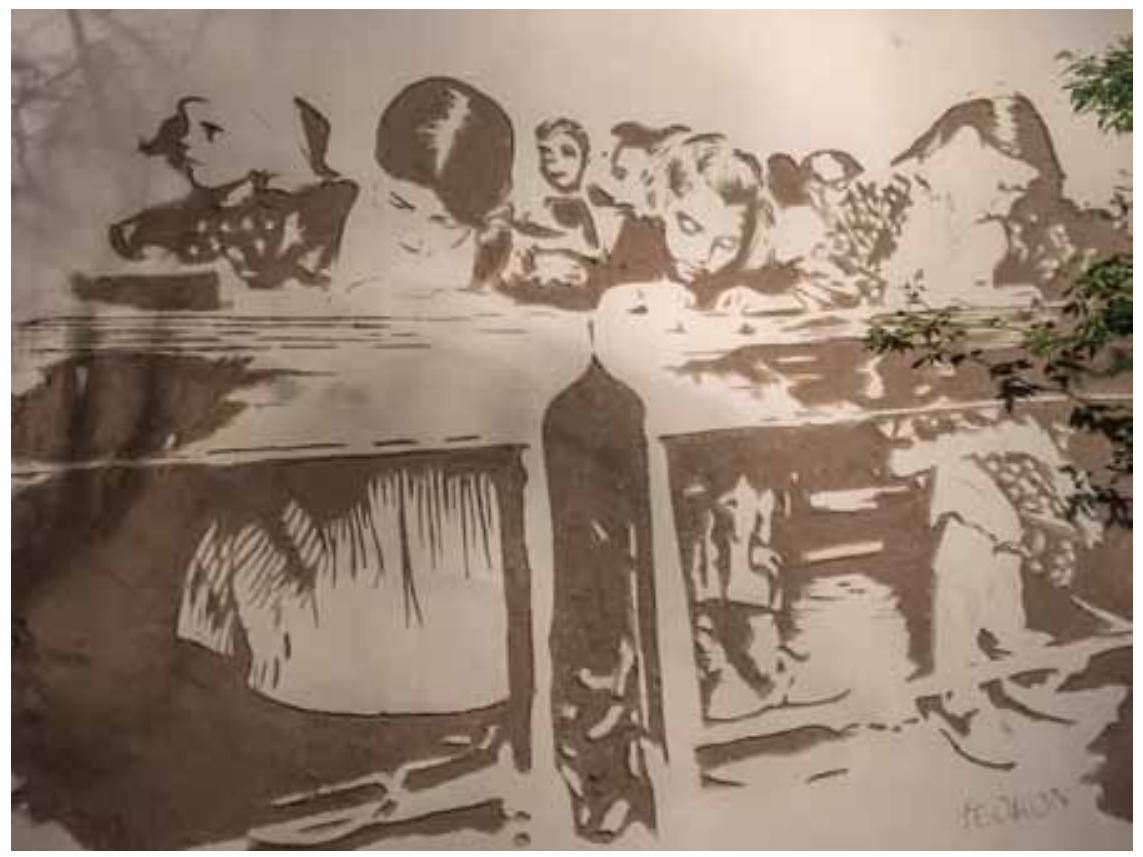

FIGURE 5: Mural on the wall of a restaurant in Exarcheia, Athens, a former primary school and a location where a number of important research conversations took place. Photograph ${ }^{\oplus}$ Melissa Nolas 
is, took place on the move, following desire lines through various cities. The majority of this analysis on the move, over time, made its way into articles, blog writing, or other formal written output (see also Cerwonka and Malkki 2007).

Thinking of our meanderings and transformations as experiences in which desire lines were forged by amateurs also shaped the way we approached other aspects of the project. Thinking about the research through 'desire lines' opened up routes for experimentation. The research sat at the interface of ethnographic and cultural work, the latter involving an exhibition and eventually the creation of the first-ever children's photography archive. ${ }^{8}$ The latter cultural activity was unplanned at the bidding stage but emerged over the course of the five years when we realized that although such an archive did not exist, given how we are not accustomed to thinking of children as photographers in their own right (Nolas and Varvantakis 2019; Varvantakis and Nolas, forthcoming), we had inadvertently ended up creating one.

We have also attempted to $p(l)$ ay homage to a more oral culture of knowledge transmission through the recording of a series of podcasts wherein we discuss the lived experience of doing research and the ways in which the personal was implicated in our academic theorizing, as well as how our fieldwork resonated and shaped our personal experiences. ${ }^{9}$ Similarly, we ran a series of short blog posts capturing those moments where the personal/private met the political/public. ${ }^{10}$

The idea of desire lines also influenced the design and delivery of research methods training we carried out during the project. ${ }^{11}$ We ran four research methods workshops in multi-modal ethnography that were designed on the principles of experiential learning. In an attempt to scale out the idea of the 'shared drink'-a space of commensuality, of exchange and of memory creation (Seremetakis 1994) — workshops were run in community spaces outside the university; serving workshop participants with good food was an integral part of the design. The journal we co-edit, entanglements: experiments in multi-modal ethnography, ${ }^{12}$ emerged from discussions and experiences at these workshops and an attempt to create a virtual space in which such discussions might be continued (e.g., see the récits section of the journal). Such experiments were responses to the fieldwork and the cultural context writ large. They were intuitions and reflexes that unfolded into proposals and then practices, their rationalization, as with many a cultural practice, a retrospective activity.

\section{Contradictions of Researcher Agency in the Neo-liberal University}

Of course, and very obviously, we are not amateurs in the strictest sense. We are both highly trained and experienced researchers who were remunerated for our labor. Many of the activities described above were made possible due 
to receiving an ERC grant, and this event in itself is riddled with contradictions. The ERC is part of the European Commission's research and innovation funding strategy. The European Commission is often portrayed as an 'opaque' bureaucracy (Williams 2019); indeed, pro-Brexit narratives have attempted to position the EU as an opaque and expensive bureaucracy. Yet it is a modestly sized employer, ${ }^{13}$ tiny compared to some of the world's largest organizations. ${ }^{14}$ Nevertheless, it is a research bureaucracy that makes the forging of desire lines possible (as described above). Unlike many funding streams of the EU and other funders, the ERC has the unusual (for the contemporary moment) characteristic of allowing for extended temporalities that are in step with the conditions necessary for the creative practice of ethnographic research. In George Marcus's (2016: 144) words: "As every anthropologist knows, 'good' ethnography takes all of the time in the (Western) world." But the awards funded by the ERC in its different schemes are also intended for individual career development within the professional landscape of the contemporary academy; they are grants for forging straight lines. As such, these grants resonate with the contemporary moment of entrepreneurial selves and marketized higher educational systems. It could even be argued that such grants help reinforce marketization and entrepreneurship. ${ }^{15}$ And they most probably do. However, they can also do much more that challenges the so-called neo-liberal university.

So while we are not amateurs in a strict sense, by approaching our experiences $a$ s if we were, there is much that we might retain in that spirit in order to support creative research practices and each other. Surrendering to children's play and working as we did, as a team, forced us to rethink both the individual career narratives expected by our employers as well as our profession (e.g., the practice of writing the individual staff pages, something we both struggle with and dislike). Playing with children literally made us more aware of our bodies (Varvantakis and Nolas 2019) - an awareness often erased by contemporary work practices, such as eating lunch at a desk or responding to e-mails late into the night-and our 'shared drinks' foregrounded our material selves as bodies that eat, drink, laugh, sleep, and so forth. While workplaces can often make one feel alienated and dehumanized, like a cog in a machine, play offered us an opportunity for human connection. Becoming 'co-' in all of the aforementioned project activities (colleagues, collaborators, companions, conspirators, comrades) enabled the creation of a safe space to emerge in which, in Goffman's (1989: 128) terms, making “a horse's ass” of ourselves could take place in the pursuit of good ethnography, and could later also be storied for others. After all, to love what you do, together, for its intrinsic value, could not be more of a critique and irritation to the extrinsic logic that drives pernicious bureaucratic practices.

None of this is sufficient in and of itself to meaningfully reverse the structural violence(s) that can be affected through the orthodoxy of the marketization of 
the higher education context in which we both work. Problematically, play itself has already been co-opted by management theory and practice, and institutionalized by some companies (Mainemelis and Ronson 2006), in aid of achieving new products, services, and infrastructures. This is not what we are suggesting by our focus on play. Our engagement with play was not instrumental: it was context and situation specific, it was unanticipated, it emerged and was encountered, and, as already described, it shocked us (in the Deleuzian sense). Ultimately, however, it opened us up to fundamental values and ethical practices of sociality (Eriksen 2015), of taking care of ourselves, of each other, and of others we work with. For other researchers, in other research contexts, the 'shock to the system' and the deviations it can offer might emerge in a different guise. What we are suggesting is that, either way, there may be more 'joy' (Graeber 2015) in navigating the contradictions of the so-called neo-liberal academy than we often allow ourselves to admit, especially when such navigation happens together with others. And a 'shared drink' definitely helps in spotting and plotting lines of desire through otherwise grid-like institutions.

\section{Acknowledgments}

The research was funded by the European Research Council Starting Grant (ERC-StG-335514) awarded to Sevasti-Melissa Nolas. The article is based on experiences, ideas, and discussions over the last five years of both Nolas and Varvantakis, who have contributed equally to the article. Other colleagues, collaborators, companions, co-conspirators, and comrades whom we would like to thank for being an integral part of this journey are Vinnarasan Aruldoss, Claire Prater, Robyn Long, and Madhavi Latha. We thank Michael Guggenheim for his enthusiastic and critical review of an earlier draft of this article. We are also grateful for Martin Holbraad's editorial interventions and openness, as well as the comments of two anonymous reviewers. We would also like to thank participants at all three Making Connections workshops in London (November 2017, March 2018) and Athens (February 2018) and the summer school in Tirupati (June 2018) for their critical and constructive comments on the idea of ethnography as a practice of desire lines. Parts of this article have appeared as a blog post co-authored by Varvantakis and Nolas. An earlier version of the article was presented at the European Association of Social Anthropological Conference (Colleex Network) in Stockholm, Sweden, on 16 August 2018 and the European Sociological Association Qualitative Research Network meeting in St. Gallen, Switzerland, on 8 September 2018. We thank colleagues in attendance at both meetings for their feedback. Any deviations from that feedback are entirely our own. 
Sevasti-Melissa Nolas is a Senior Lecturer in Sociology at Goldsmiths, University of London. Her research areas include human agency and lived experience, childhood, youth and family lives, civic and political practices across the lifecourse, and publics-creating methodologies. She is the Principal Investigator of the ERC-funded Connectors Study and the co-editor of entanglements: experiments in multi-modal ethnography. E-mail: s.nolas@gold.ac.uk

Christos Varvantakis is an anthropologist working at Goldsmiths, University of London, carrying out research in Athens for the ERC-funded Connectors Study. His research areas are childhood, politics, contested urban environments, and visual and multi-modal research methodologies. He is the co-editor of entanglements: experiments in multi-modal ethnography and the Head of Programming of the Athens Ethnographic Film Festival. E-mail: c.varvantakis@gold.ac.uk

\section{Notes}

1. See also the Network for Precarious Anthropologists at https://www.cas-sca. ca//groups-and-networks/network-for-precarious-anthropologists.

2. In addition to the references cited, see also our blog writing over the past few years on collective action, solidarity, and activism at the Childhood Publics website: https://www.childhoodpublics.org/blog/tag/activism/.

3. For those interested in the ethnographic write-up underpinning the narrative of this article, see Varvantakis and Nolas (2019). A full bibliography of activities and publications from the program can be found on the Childhood Publics website at https://childhoodpublics.org/communications/writing/.

4. Taussig's talk can be found at http://www.tate.org.uk/context-comment/audio /anthropologies-present-michael-taussig-i-swear-i-saw. The matter discussed here appears at about 1 hour and 31 minutes into the recording.

5. For more on Vitae, a non-profit organization that describes itself as a global leader in supporting the professional development of researchers, see https:// www.vitae.ac.uk/about-us/our-history.

6. See also the forum section in the spring 2018 issue of this journal about what constitutes 'analysis' in ethnography (Holbraad et al. 2018).

7. We would like to acknowledge the participation and contribution of our colleague Vinnarasan Aruldoss during these various meetings.

8. The Children's Photography Archive, the first of its kind, can be viewed at https://cpa.childhoodpublics.org/archives/childrens-photography-archive/.

9. Our podcasts can be found at https://www.childhoodpublics.org/podcasts/.

10. See https://childhoodpublics.org/blog/category/photo-stories/.

11. For more on this aspect of our project, see https://childhoodpublics.org/events /making-connections-an-introduction-to-multimodal-ethnography/. 
12. Our co-edited journal can be explored at https://entanglementsjournal.org.

13. For information about the EU's administration staff, see https://europa.eu/ european-union/about-eu/figures/administration_en.

14. Wikipedia lists the largest employers in the world at https://en.wikipedia. org/wiki/List_of_largest_employers, and Full Fact, a non-profit organization that checks facts, assesses the claim that the EU employs fewer people than Derbyshire at https://fullfact.org/europe/eu-debate-does-brussels -employ-fewer-bureaucrats-derbyshire/.

15. These grants receive full economic funding and provide healthy revenues for individual departments and universities.

\section{References}

Aruldoss, Vinnarasan. 2018. “Banter in Fieldwork.” entanglements: experiments in multimodal ethnography 1 (1): 5-6.

Bacevic, Jana. 2018. "University under Attack? Politics, Contestation and Agency beyond the 'Neoliberal University." In The Idea of the University: Contemporary Perspectives, Vol. 2, ed. Ronald Barnett and Michael A. Peters, 21-36. New York: Peter Lang.

Benjamin, Walter. (1973) 1997. Charles Baudelaire: A Lyric Poet in the Era of High Capitalism. Trans. Harry Zohn. London: Verso Books.

Bourdieu, Pierre. 1999. “Understanding.” In The Weight of the World: Social Suffering in Contemporary Society, ed. Pierre Bourdieu; trans. Priscilla P. Ferguson, 607-626. Stanford, CA: Stanford University Press.

Brown, Nina, Thomas McIlwraith, and Laura Tubelle de González, eds. 2017. Perspectives: An Open Invitation to Cultural Anthropology. Society for Anthropology in Community Colleges. http://perspectives.americananthro.org/.

Cerwonka, Allaine, and Liisa H. Malkki. 2007. Improvising Theory: Process and Temporality in Ethnographic Fieldwork. Chicago: University of Chicago Press.

Dalsgaard, Steffen. 2013. "The Field as a Temporal Entity and the Challenges of the Contemporary." Social Anthropology 21 (2): 213-225. https://doi.org/ 10.1111/1469-8676.12012.

Deleuze, Gilles. 1994. Difference and Repetition. Trans. Paul Patton. New York: Columbia University Press.

Deleuze, Gilles, and Félix Guattari. 1983. Anti-Oedipus: Capitalism and Schizophrenia. Trans. Robert Hurley, Mark Seem, and Helen R. Lane. Minneapolis: University of Minnesota Press.

Eriksen, Thomas H., James Laidlaw, Jonathan Mair, Keir Martin, and Soumhya Venkatesen. 2015. “Opposing the Motion: The Neoliberal Person.” In “Debate: 'The Concept of Neoliberalism Has Become an Obstacle to the Anthropological Understanding of the Twenty-First Century." Journal of the Royal Anthropological Institute (n.s.) 21 (4): 911-923. https://rai.onlinelibrary.wiley.com/ doi/10.1111/1467-9655.12294. 
Giabiconi, Julie. 2013. "Serendipity ... mon amour? On Discomfort as a Prerequisite for Anthropological Knowledge.” Social Anthropology 21 (2): 199-212. https://doi.org/10.1111/1469-8676.12013.

Gidley, Ben. 2009. "A Note on the Awkwardness of the Ethnographer." Sociological Review 57 (3): 526-529. https://doi.org/10.1111/j.1467-954X.2009.01853.x.

Goffman, Erving. 1989. “On Fieldwork.” Journal of Contemporary Ethnography 18 (2): 123-132. https://journals.sagepub.com/doi/abs/10.1177/ 089124189018002001.

Graeber, David. 2014. "Anthropology and the Rise of the Professional-Managerial Class.” HAU: Journal of Ethnographic Theory 4 (3): 73-88. https://doi.org /10.14318/hau4.3.007.

Graeber, David. 2015. The Utopia of Rules: On Technology, Stupidity, and the Secret Joys of Bureaucracy. New York: Melville House.

Guggenheim, Michael, Bernd Kräftner, and Judith Kröll. 2017. "Creating Idiotic Speculators: Disaster Cosmopolitics in the Sandbox." In Speculative Research: The Lure of Possible Futures, ed. Alex Wilkie, Martin Savrangksy, and Marsha Rosengarten, 145-162. London: Routledge.

Holbraad, Martin, Sarah Green, Alberto Corsín Jiménez, Veena Das, Nurit Bird-David, Eduardo Kohn, Ghassan Hage, Laura Bear, Hannah Knox, and Bruce Kapferer. 2018. "Forum: What Is Analysis? Between Theory, Ethnography, and Method.” Social Analysis 62 (1): 1-30. https://doi.org/10.3167/ sa.2018.620103.

Ingold, Tim. 2007. Lines: A Brief History. London: Routledge.

Ingold, Tim. 2017. "Anthropology contra Ethnography." HAU: Journal of Ethnographic Theory 7 (1): 21-26. https://doi.org/10.14318/hau7.1.005.

Irving, Andrew. 2017. The Art of Life and Death: Radical Aesthetics and Ethnographic Practice. Chicago: HAU Books.

Jacobs, Jane. 1961. The Death and Life of Great American Cities. New York: Random House.

Kapferer, Bruce. 2018. "From the Outside In: Anthropology as a Dialectic of Unsettlement.” Social Analysis 62 (1): 27-30. https://doi.org/10.3167/ sa.2018.620103.

Katz, Cindi. 2004. Growing Up Global: Economic Restructuring and Children's Everyday Lives. Minneapolis: University of Minnesota Press.

Le Courant, Stefan. 2013. "What Can We Learn from a 'Liar' and a 'Madman'? Serendipity and Double Commitment during Fieldwork." Social Anthropology 21 (2): 186-198. https://doi.org/10.1111/1469-8676.12015.

Lutz, Catherine. 2017. "What Matters.” Cultural Anthropology 32 (2): 181-191. https://doi.org/10.14506/ca32.2.02.

Mainemelis, Charalampos, and Sarah Ronson. 2006. "Ideas Are Born in Fields of Play: Towards a Theory of Play and Creativity in Organizational Settings.” Research in Organizational Behaviour: An Annual Series of Analytical Essays and Critical Reviews 27: 81-31.

Marcus, George. 2016. "Afterword: Ethnography between the Virtue of Patience and the Anxiety of Belatedness Once Coevalness Is Embraced." In Time and 
the Field, ed. Steffen Dalsgaard and Morten Nielsen, 143-155. New York: Berghahn Books.

Montgomery, Heather. 2009. An Introduction to Childhood: Anthropological Perspectives on Children's Lives. Chichester: Wiley-Blackwell.

Morley, Louise, Simon Marginson, and Jill Blackmore. 2014. "Education and Neoliberal Globalization.” British Journal of Sociology of Education 35 (3): 457-468. https://doi.org/10.1080/01425692.2014.893072.

Nelson, Maggie. 2016. The Argonauts. London: Melville House.

Nieuwenhuys, Olga. 2010. "Keep Asking: Why Childhood? Why Children? Why Global?” Childhood 17 (3): 291-296.

Nolas, Sevasti-Melissa. 2014. "Towards a New Theory of Practice for Community Health Psychology.” Journal of Health Psychology 19 (1): 126-136. https://doi. org/10.1177/1359105313500252.

Nolas, Sevasti-Melissa, and Christos Varvantakis. 2019. The Child's Gaze Exhibition Catalogue. Connectors Study. https://childhoodpublics.org/ communications/writing/exhibition-catalogues/.

Nolas, Sevasti-Melissa, Christos Varvantakis, and Vinnarasan Aruldoss. 2016. “(Im)possible Conversations? Activism, Childhood and Everyday Life.” Journal of Social and Political Psychology 4 (1): 252-265. https://doi.org/10.5964/jspp. v4i1.536.

Nolas, Sevasti-Melissa, Christos Varvantakis, and Vinnarasan Aruldoss. 2017. "Political Activism across the Life Course." Contemporary Social Science 12 (1-2): 1-12.

Rivoal, Isabelle, and Noel B. Salazar. 2013. "Contemporary Ethnographic Practice and the Value of Serendipity.” Social Anthropology 21 (2): 178-185. https://doi. org/10.1111/1469-8676.12026.

Rosen, Rachel. 2017. "Play as Activism? Early Childhood and (Inter)generational Politics." Contemporary Social Science 12 (1-2): 110-122. https://doi.org/10.1080 /21582041.2017.1324174.

Sassen, Saskia, and Nigel Warburton. 2014. "Saskia Sassen on Before Method.” Social Science Space. http://www.socialsciencespace.com/2014/05/saskia -sassen-on-before-method/.

Sedgwick, Mitchell W. 2018. "Entwined Biographies of Work and Trauma: Taking Time in the Study of Corporations.” Social Anthropology 26 (1): 74-87. https:// doi.org/10.1111/1469-8676.12488.

Seremetakis, C. Nadia, ed. 1994. The Senses Still: Perception and Memory as Material Culture in Modernity. Boulder, CO: Westview Press.

Stavrides, Stavros. 1999. “Towards an Anthropology of the Doorstep.” [In Greek.] Outopia 33: 107-121.

Taussig, Michael. 1993. Mimesis and Alterity: A Particular History of the Senses. New York: Routledge.

Varvantakis, Christos. 2016. "In Line: A Photo Essay on Entering a School in Bangalore.” In Exploring Alterity in a Globalized World, ed. Christoph Wulf, 263-276. New York: Routledge.

Varvantakis, Christos. 2018. "'Like the Palm of My Hand': Children and Public Space in Central Athens.” Livingmaps Review 4 (1): 1-12. 
Varvantakis, Christos, and Sevasti-Melissa Nolas. 2019. "Metaphors We Experiment with in Multimodal Ethnography.” International Journal of Social Research Methodology 22 (4): 365-378. https://doi.org/10.1080/13645579.2019 .1574953 .

Varvantakis, Christos, and Sevasti-Melissa Nolas. Forthcoming. "Children as Photographers.” The Sage Encyclopedia of Children and Childhood Studies, ed. Daniel T. Cook. London: Sage.

Williams, Richard J. 2019. “The EU's Buildings Are as Opaque as Its Bureaucracy.” Foreign Policy, 13 April. https://foreignpolicy.com/2019/04/13/the -eus-buildings-are-as-opaque-as-its-bureaucracy/. 